Revue Française de Civilisation Britannique

\title{
Was Boris Johnson's One-Nation Post-Electoral Pledge Sincere?
}

La Promesse post-électorale de Boris Johnson d'être un conservateur Onenation était-elle sincère?

\section{Alicia-Dorothy Mornington}

\section{OpenEdition}

\section{Journals}

Electronic version

URL: http://journals.openedition.org/rfcb/5693

DOI: $10.4000 /$ rfcb.5693

ISSN: 2429-4373

\section{Publisher}

CRECIB - Centre de recherche et d'études en civilisation britannique

\section{Electronic reference}

Alicia-Dorothy Mornington, « Was Boris Johnson's One-Nation Post-Electoral Pledge Sincere? », Revue Française de Civilisation Britannique [Online], XXV-3 | 2020, Online since 10 September 2020, connection on 10 September 2020. URL : http://journals.openedition.org/rfcb/5693 ; DOI : https://doi.org/ $10.4000 /$ rfcb.5693

This text was automatically generated on 10 September 2020 .

\section{cc) (†)}

Revue française de civilisation britannique est mis à disposition selon les termes de la licence Creative Commons Attribution - Pas d'Utilisation Commerciale - Pas de Modification 4.0 International. 


\title{
Was Boris Johnson's One-Nation Post-Electoral Pledge Sincere?
}

\author{
La Promesse post-électorale de Boris Johnson d'être un conservateur One- \\ nation était-elle sincère?
}

Alicia-Dorothy Mornington

\section{Introduction}

1 During his Oxonian days, Johnson is said to have "made no secret of his desire to be Prime Minister one day, and not just a run-of-the-mill, common-or-garden PM, but up there with Gladstone and Disraeli"'. In the aftermath of the 2019 general election, given his unpredicted landslide victory, this aspiration appeared possible. Thanks to him, the Conservative party was able to claim its largest majority since 1987. In the days following the election, Boris Johnson repetitively pledged to fashion a "one-nation government".

2 This article proposes to understand what use was made of the "one-nation" idiom in the wake of the elections until January 2020. Was it a political jingle, aimed at rallying working class voters? Or was it a genuine commitment to a particular blend of conservatism, one that would work for the entire country? This article will try answering this question by first defining one-nation conservatism, and explaining how Johnson's sweeping victory could be read as de facto one-nation. The second part will discuss one-nation conservatism in historical perspective - both in Johnson's personal history, and Britain's political spectrum since Disraeli. The last part will argue that serious doubts may be held concerning the genuineness of Johnson's one-nation promise, given internal party politics in the conservative party. 


\section{From Clwyd South to Surrey Heath: a de facto one- nation government?}

3 The morning after his overwhelming victory, Boris Johnson declared: "we must recognise the incredible reality that we now speak as a One-nation Conservative party literally for everyone from Woking to Workington; from Kensington, I'm proud to say, to Clwyd South; from Surrey Heath, to Sedgefield; from Wimbledon to Wolverhampton ${ }^{2}$." In the sequence following the elections results, Johnson started copiously referring to the one-nation doctrine, a term which had not been used much during the campaign - it is remarkably absent from the conservative manifesto that had focused primarily on Brexit ${ }^{3}$.

One-nation Conservatism can be described as a progressive attempt to combine “ compassion and competence $e^{4 "}$. This doctrine constitutes a branch of conservatism ${ }^{5}$ and was coined by Benjamin Disraeli, whom Johnson regularly cites as his model and who turned the political tables in his time. He was Prime Minister briefly in 1868, then again from 1874 to 1880 and left an indelible mark on British politics, often depicted as a flamboyant novelist and shrewd politician able to charm Queen Victoria. In his famous novel Sybil published in 1845, Disraeli famously described Britain as composed of "two nations; between whom there is no intercourse and no sympathy; who are as ignorant of each other's habits, thoughts and feelings, as if they were dwellers in different zones, or inhabitants of different planets (...) the rich and the poor ${ }^{6}$. Conservatives, he believed, could help breach this divide. To do, important investments in terms of infrastructure, access to healthcare, education, had to be conceded to help the working class catch up with standards of living of the more privileged members of society. Disraeli was one of the first members of the conservative party to predict that conservatism could appeal to the nation as a whole, not just the landed interests, a thesis which was contested in his own party at the time, as it questioned the historical Tory credo. Catherine Marshall writes that "when Gladstone would later declare that he would 'back the masses against the classes', Disraeli was saying that the natural alliance was between the higher classes and the masses making his type of conservatism a one-nation popular type of Toryism"'.

5 To understand one-nation conservatism, we must go back to the "old" Tory party, which retraced its footsteps back to the English civil war, where Cavaliers supported the crown against Parliament - the term tory was first used during the Exclusion Bill crisis in the late $17^{\text {th }}$ century. In the $18^{\text {th }}$ century, the Tory party was forced to agree to an increase in the influence of Parliament but continued to defend the interests of landowners and the clergy. The party was dissolved in 1834, drawing on the consequences of its inability to oppose the Great Reform Act of 1832, the first electoral reform since the Tudor, which granted the ballot to the industrial cities in Northern England. It was replaced by the Conservative party, founded by Robert Peel, and accepted the idea of institutional reform. The term tory nevertheless continued to be used and became virtually synonymous with Conservative.

Without Disraeli's political genius, the Conservative Party may well have fallen between the cracks of history. Disraeli realised the conservative party could gather cross-crass appeal. His idea of a conservative party that could cater for the whole of the nation was based on increased spending on social policy, particularly in the area of health. In his famous 1872 speech at the Crystal Palace, Disraeli had stated that one of the "great object of the Tory party (...) is the elevation of the condition of the people ${ }^{8 "}$. This would allow the party to present itself as defender of the whole nation and no longer as that of a 
caste. Disraeli was able to own the 1867 electoral Reform Bill9, enfranchising thousands of working-class men. He was not thanked for it though as he lost the 1868 general election.

Philip Lynch contends that "behind the one-nation rhetoric of a party with cross-class appeal and a clear social programme, the reality was one of limited social legislation ${ }^{10 "}$. Social hierarchy was not to be forsaken, but better living conditions could be pushed for by increasing social spending. This "progressive" program was not disinterested. As Disraeli put it "the castle cannot rest if the cottage is not happy", which allows Peter Dorey to argue one-nation conservatism is a philosophy of enlightened self-interest: "it behoves the propertied or moneyed classes to ensure that the working classes enjoy tolerable material conditions, and are accorded a certain degree of respect, if only to minimise the likelihood that those workers will turn against their masters or established political leaders ${ }^{11}$ ". One-nation conservatism was thus a way to ensure social peace. For all its promise of bridging inequalities, one-nation conservatism was however entrenched in deeply hierarchical values is thus best described as paternalistic. Another subsequent Disraeli was following such a path was that the classical British parliamentary government was progressively transitioning towards a two-party system in the 1870s, which was to rely on a growing number of voters. For Catherine Marshall "Disraeli foresaw that if Parliamentary sovereignty was to be compatible with popular sovereignty, the only way to do so was to have organised parties which controlled their representatives in Parliament"12. In this sense, Disraeli was the first modern conservative leader of the Conservative Party.

8 When Johnson said he was forming a one-nation government in the wake of the elections results, he was therefore making a promise - to level social inequality - but he was also merely describing a factual situation. To understand his one-nation promise, we must turn to the election results. An overwhelming majority of Britons across the kingdom allowed him to enter 10 Downing street. For the first time in decades, a conservative candidate had managed to secure the working class vote. Boris Johnson is de facto a one-nation conservative, in the sense that he was able to appeal to the wealthiest as well as the most economically deprived areas.

The 2019 election bestowed upon Johnson a landslide majority of 80 seats in the House of Commons, and $43,6 \%$ of the vote ${ }^{13}$. This victory brought Labour to its knees, as conservatives were able to turn the political tide and win many constituencies in the traditional working-class Labour heartland. The so-called "red wall" of labour voters, which stretched from Wales across to the Midlands and the North of England, former mining and industrial centres, was smashed to smithereens by a powerful conservative wave that engulfed all of England and Wales but for the few Labour atolls that withstood the shock, mainly constituencies around major cities such as London, Manchester, Newcastle, Liverpool or Cardiff. The epitome of this resounding victory for the conservatives is possibly the highly symbolic constituencies that turned blue, such as Blyth Valley, a mining town affected by unemployment and poverty, which returned a Conservative MP for the first time in 70 years. Although the Conservatives won this seat with a majority of only 712 votes; the move is no less historic.

This conservative surge is partly explained by the Brexit referendum. Constituencies that voted leave vastly voted for Johnson, as he had promised to "get Brexit done", a refrain repeated ad nauseum throughout the campaign ${ }^{14}$. Under Jeremy Corbyn's leadership, his divisive personality, accusations of anti-Semitism, and the Labour 
party's noncommittal position on Brexit led to its thumping defeat in its traditional voter reserve, despite facing an incumbent Tory party that had implemented policies of economic austerity since 2010. The will to leave the EU appears to have been a major factor. For example, in Blyth, 6 out of 10 voters voted in favour of leaving the EU, despite being riddled with high unemployment. Therefore, in a sense, as far as England is concerned, Johnson's success bridges class divide.

\section{Johnson's one-nation commitment in historical perspective}

11 Johnson's repetitive use of the one-nation mantra can be understood as a serious pledge to apply more socially generous policies. On the $13^{\text {th }}$ of December, he declared that once Brexit would be successfully completed, he would finally be able to focus on the fate of the National Health Service (NHS) and pledged that: "This one-nation Conservative Government will massively increase our investment in the NHS, the health service that represents the very best of our country, with a single, beautiful idea that whoever we are rich, poor, young, old - the NHS is there for us when we are sick, and every day that service performs miracles. And that is why the NHS is this one-nation Conservative Government's top priority ${ }^{15}$ ". Promises to fund the NHS echoed the Leave campaign's focus on the NHS, reflecting the country's attachment to this institution. Johnson had also promised to end austerity as soon as he was elected, which suggest a sincere commitment to onenation policies.

To show he was serious, one week after the results Johnson pledged to increase the NHS budget by $€ 34$ billion during his term. This is consistent with him declaring he would "repay" votes that had been lent to the Tories: "I want to speak directly to those who made it possible and to all those who voted for us, for the first time, all those whose pencils may have wavered over the ballot and who heard the voices of their parents and their grandparents whispering anxiously in their ears. I say thank you for the trust you have placed in us and in me and we will work round the clock to repay your trust and to deliver on your priorities ${ }^{16 "}$. One way to effectively pay back more deprived voters is by massively investing in underprivileged areas, namely the Midlands and North east of England. In the early days of his election, Johnson appeared to be making significant steps towards this. For example, in December in Sedgefield, Tony Blair's former seat, he announced a "spending spree" to cater to the needs of his new conservative voters, using a $£ 80$ billion fund for infrastructure spending in Northern England ${ }^{17}$.

13 Additionally, plans to relocate the House of Lords in York were presented in January as a means "to level up" the rest of country with London ${ }^{18}$. In his New Year message on Twitter, he promised to focus on "spreading opportunity to every corner of our country" His programme thus appeared at the end of January to be aiming at one-nation policies, even though sceptics would be waiting to see whether these symbolic measures would be able to make a real difference to these seriously deprived formerly industrial areas. Will these proposals be sufficient to successfully attenuate inequalities, only time will tell?

We may wonder whether Johnson's one-nation announcements constituted a kneejerk reaction to an unexpected support from underprivileged areas after the election. At first blush, this hypothesis appears plausible: in order to be re-elected, new votes must 
be secured, and one-nation policies constitute reasonable means to secure a second term. This is not the case however, and for two reasons that will be discussed in turn.

First, Johnson's one-nation self-branding is by no means recent. He portrayed himself as a one-nation conservative ever since he was campaigning to become Mayor of London. In a 2010 interview for the Telegraph he declared "I'm a one-nation Tory. There is a duty on the part of the rich to the poor and to the needy, but you are not going to help people express that duty and satisfy it if you punish them fiscally so viciously that they leave this city and this country ${ }^{20}$." In a cabinet meeting in September 2019, Johnson allegedly described himself as "basically a Brexity Hezza", in reference to Michael Heseltine, staunch proEuropean who advocated for substantial spending in deprived areas and was a prominent member of the Thatcher and Major governments. Therefore, arguing that the one-nation branding was a spontaneous reaction to winning Blyth and the likes is mistaken. Moreover, Johnson's legacy as a Mayor suggests some consistency with the one-nation label. As a mayor of London, he was generally seen as a centrist, having supported the London living wage for example or amnesty for illegal migrants and publicly endorsed Obama.

To understand the depth of Johnson's post electoral one-nation pledge, we now need to examine the precise ideological content of one-nation conservatism. Rather than a genuine commitment to Disraeli's views, it is often a blurry catch phrase to describe policies more in tune with centrist or left leaning interests. As Robert Walsha argues, " politicians have typically summoned the spirit of Disraeli when attempting to align themselves with progress or respectability in the Conservative Party, advocating the need to appeal beyond the party's core natural vote, repudiating class as a desirable basis for party-political division, advancing the case for cooperation and harmony in industrial relations, justifying policies of social and other reforms, or expressing concern for the plight of the impoverished ${ }^{21}$ ". In other words, the term one-nation signals an attempt to reach voters who do not typically vote Conservative, and therefore justify funding more socially generous reforms to coax them. Walsha claims "the popular perception of the One-nation Conservative is of a business-minded and professional career politician (...) attentive to issues of social policy, and emphasising the virtues of 'classlessness' and equality of opportunity 22". Johnson was perhaps trying to echo this popular perception, in order to try reinforcing his popular support, which would be essential for Brexit negotiations, after three years of deep-seated divisions caused by the Brexit referendum of 2016.

17 Johnson is not the first to be claiming to be a one-nation conservative since his illustrious predecessor Disraeli. Since the latter's terms in office, many conservatives have described themselves as such, representing sometimes as a minority of the party, sometimes a dominant force. The history of this ideological branch of the British Right reflects transformations of the British political spectrum. After Disraeli's paternalistic brand of conservatism, in the late $19^{\text {th }}$ century, the Tory party embraced the dogma of unbridled free trade and let go of the one-nation conservatism. Since then, the onenation ideology has gone in and out of fashion.

According to Hugh Bochel, during the 1950-60s, one-nation conservatism was at its peak as it was the most suited to converse with Labour's post-war momentum of public expenses led by Atlee and the general sense of national unity ${ }^{23}$. Harold Macmillan, Prime Minister from 1957 to 1963 is a representative of this doctrine, insisting on generous social measures, in particular in terms of housing. Edward Heath is another prime candidate of a one-nation policy, albeit an unsuccessful one ${ }^{24}$. Yet it started 
waning in the 1970s and was in sharp decline during the Thatcher era ${ }^{25}$. For Walsha, "by the 1980s, political commentators commonly distinguished Conservatism in terms of a dichotomy between modern, right-wing 'Thatcherism', and old- fashioned, socially compassionate 'onenation"'. In fact, according to Robert Blake, anyone in Thatcher's cabinet who either praised Disraeli or claimed to be one-nation was safely assumed to be critical of her ${ }^{26}$. One-Nation Conservatism was seen as a dated, paternalistic stance, that was far too costly of taxpayers' money ${ }^{27}$, contradicting the Hayekian theory of laissez-faire ${ }^{28}$. Evans disagrees slightly with this, he argues that Thatcher was in fact sometimes prone to using Disraeli's legacy of One-nation by interpreting it as patriotism instead of paternalism, which amounts to emptying it of its ideological substance ${ }^{29}$.

The term one-nation was then rehabilitated in the 1990s, first under John Mayor who sought a classless society and then unexpectedly hijacked by the Labour Party ${ }^{30}$. It was Tony Blair's "successful capture of the term, to market Labour's shift to the political centreground, that helped his party to secure so huge a victory at the 1997 general election ${ }^{31}$ ». Further on, in 2012, Ed Miliband rebranded his party as "one-nation Labour" ${ }^{2}$, in an attempt to shift the party slightly more to the Left and win the 2015 elections after his party's crushing defeat of 2010 .

David Cameron did the same and one-nation compassionate conservatism made a notable comeback in the conservative party in the mid-2010s, as Agnès AlexandreCollier argues ${ }^{33}$. According to her, since 1965, the conservative party has evolved to become a "catch-all party » in the sense of casting its ideological net far and wide ${ }^{34}$. We could argue that after New Labour, the "one-nation" catchphrase become the epitome of the catch-all nature of the conservative party under the leadership of David Cameron, who fully embraced the term and applied it to every possible aspect of government. As Peter Dorey contends, after three crushing electoral defeats since 1997, Cameron decided to reposition the party's ideological stance away from hard-core free market Thatcherism and towards a more compassionate centre, despite internal hostility to this project ${ }^{35}$. Adopting Disraelian policies ${ }^{36}$, and the one-nation motto would be an effective signal for this purpose, and this was to be particularly striking in 2015, after the party's stunning re-election. In 2015 "one-nation" was used ad libitum. To cite only a few occurrences, Cameron spoke of a "one-nation plan to spread home ownership ${ }^{37}$ ", invoked a "one-nation government to close the pay gap ${ }^{38 ", ~ s t a t e d ~ t h a t ~ " a s ~ a ~}$ one-nation government we will keep on backing British farmers ${ }^{39 "}$ ", mentioned a "one-nation

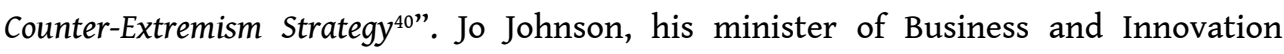

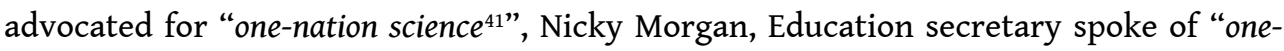
nation education ${ }^{42 "}$ ", Ian Duncan Smith his Work and Pensions Secretary declared the conservative government wage rise was proof of " a one-nation government helping hardworking people ${ }^{43}$ ".

What sense can be made of this iniquitousness of the one-nation slogan? For David Seawright the use of one-nation ideology in the conservative party was a strategy "to aid a process of depoliticisation" ${ }^{44}$. The catchphrase was used to suggest the party was working for the nation as a whole and not a specific class, to suppress dissension. In a sense, the ubiquity of Cameron's one-nation is on par with Thatcher's TINA strategy (there is no alternative) ${ }^{45}$. The goal of these catchphrases is to convince voters the government is acting rationally, and not pursuing policies that would favour one class or group over another. These tag lines are be used to stifle antagonism. Seawright goes as far as saying that one-nation is in fact a myth of the conservative party, having lost 
its specific meaning over the years, which explains why two contenders to the party leadership bid in 2003, Ian Duncan Smith and Ken Clarke, who held radically opposed views, both claimed to be one-nation Tories ${ }^{46}$. From a historical perspective, the use of the term one-nation therefore by no means implies a genuine commitment to centrist, paternalistic policies, and Johnson's pledge must be read with that in mind.

For his one-nation incantations, it could hardly be argued that Cameron's policies helped bridge the gap between the poor and the rich, to put it mildly. Policies of austerity have deeply sharpened inequalities, with millions resorting to food banks ${ }^{47}$. In this light, Cameron's version of conservatism stood in sharp contrast the goal of levelling the wealth gap, and arguably was only making use of the socially acceptable face of conservatism in order to avoid being the "nasty party" Theresa May had spoken about in 2002. The one-nation phrase was a gimmick, to cloud harsh social policies. For Mark Vail, Cameron's policy was the resolution of unresolved tensions in the conservative's party's DNA, between Disraeli's welfare minded paternalism and what he calls soft Burkean traditionalism ${ }^{48}$. Johnson's one-nation conservatism appears similar to Cameron's: using it as a depoliticized catch-all phrase to fit his agenda, devoid of any connection with Disraeli's vision of a bridge between the elite and the masses.

\section{A one-nation gimmick?}

With this historical caveat in mind - one-nation conservatism has been more of a gimmick than a real commitment in recent times - we can now argue that the hypothesis of Johnson's genuine commitment to one-nation conservatism is even less convincing for two main reasons. First, in his struggle for power before the election, he found himself in sharp opposition with the official one-nation conservative group in Parliament. Former chancellors Philipp Hammond and Ken Clarke, Winston Churchill's grandson Nicolas Soames, Amber Rudd, Rory Steward who was a previous contender for the Tory party's leadership were among the 21 tory MPs who were deselected in September 2019. They were part of a one-nation caucus formed in March 2019. Their whips were removed because they opposed the prorogation of Parliament wanted by Johnson, for fear that he was trying to push for a hard Brexit. Johnson can invoke Disraeli's spirit all he likes, but ousting MPs who have been life-long supporters of a more socially compassionate branch of conservatism suggests an instrumentalization of one-nation Toryism. Some of the 21 who were deselected opposed Johnson because they are Europhiles, but also because they feared a hard Brexit would hold catastrophic consequences in terms of employment and heighten social inequalities.

Second, not only did he banish the one-nation conservative caucus group, Johnson also surrounded himself with polarising figures who do not appear as the most obvious choice to level British society. To cite only two of his most polarising close counsellors, first, the prominent architect of parliament's 2019 prorogation, Jacob Rees Mogg, was chosen to be Leader of the House of Common, although he is caricatured by his adversaries as the embodiment of upper-class reactionary elitism ${ }^{49}$. Rees Mogg's irresistible rise to fame makes him a strong figure in the Conservative party, as head of the European Research Group ${ }^{50}$, (whose name is misleading as it is a parliamentary group whose purpose is to congregate Eurosceptics). Rees Mogg embodies laissez faire conservatism: praising zero-hour contracts, and constantly opposing Theresa May's centrist policies ${ }^{51}$. He is quoted to have declared the use of food banks was "uplifting" 
because it proved people were generous, and that the only reason why more people used them was that Labour had deliberately avoided publicising their existence ${ }^{52}$. He was berated for having criticised Grenfell Tower victims as lacking common sense, for not having left the building although it was on fire ${ }^{53}$. Whether his perceived elitism is the result of an intentional vilification by the press or an apt description, it would be in any case far-fetched to think Rees Mogg is compatible with a will to level inequality, even in the most paternalistic sense.

The second chief protagonist in Johnson's entourage whose presence may suggest inconsistency with one-nation conservatism is Dominic Cummings, his controversial special political advisor. Cummings - former head of the Leave Campaign and described by the John Major as "a political anarchist (...) who could poison the political atmosphere beyond repair ${ }^{54 "}$, embodies a complex form of British libertarian nationalism ${ }^{55}$. His views are difficult to ascertain, as he usually declines interviews, and his actual influence challenging to establish. The Financial Times talks about the "myth of Dominic Cummings ": although the left leaning press is happy to have identified a villain to blame for Brexit, he could be less influential than it appears ${ }^{56}$. On his blog he declared he is "not Tory, libertarian, 'populist' or anything else ${ }^{57}$ ". Even he resists being labelled, his views appear to be as anti-establishment, pro-science, pro-disruption, often citing American libertarian venture capitalist Peter Thiel as his model. Dramatically opposed to the EU's overbearing and Whitehall's lethargic bureaucracy, his ideology seems in favour of minimising the reach of the state. Like Rees Mogg, he does not stand as the ideal candidate to help Johnson foster on nation Toryism.

A final point to suggest Johnson may not deliver one-nation Conservativism, is his attitude to the Union itself. Even if Disraeli spoke of levelling the gap between the rich and the poor, we could also read the one-nation expression in relation to the United Kingdom itself, comprised of 4 nations. Johnson's hard stance on Brexit is threatening the state of the Union, by deepening the divide between England and Scotland, that voted massively for Remain during the 2016 referendum. The SNP hit a record high in the 2019 elections, and Johnson does not appear to be making any concessions to Nicola Sturgeon in order to appease tensions. His compromise with the EU on Northern Ireland after months spent criticising May's backstop - a border in the Irish Sea, have strongly dissatisfied the DUP. His policies therefore could make a serious dent in the state of union and weaken the UK as a united single nation.

\section{Conclusion}

Will Johnson level inequalities and bring about a united nation in the UK? No one knows what the future holds. Yet for all the post victory one-nation incantations and promises to splurge money on Northern England, national unity seems doubtful for the reasons exposed above. Sacking one-nation MPs and surrounding himself with advisors who are not centrists is not a good signal. Furthermore, and given that the economic consequences of Brexit are predicted to sharpen geographical inequalities, it is unlikely that he will succeed in levelling Britons across the UK. Lord Heseltine himself is dubious of Johnson's genuineness and overall strategy, declaring to the FT that “it's a mistake to say they just have to regenerate the north (...) They have to regenerate the whole economy $y^{58}$." Moreover, given that Brexit is more likely to harm these northern regions 
the hardest, it is quite possible that the new "brexity one-nation conservatism" is in fact an oxymoron.

Is Johnson sincere? If we are to believe the former speaker of the House of Commons, John Bercow, who said the day after the results on Sky News that Johnson's only political compass was his own ambition ${ }^{59}$, then the Prime Minister will be above all pragmatic, even if it means going back on his promises. Heseltine concurs, calling him in a probable euphemism "the most flexible politician in modern times ${ }^{60}$ ". In a sense, he has this in common with Disraeli who was also a pragmatist. Therefore, whether Johnson will implement some form of one-nation conservatism or not, he will walk in the footsteps of his illustrious predecessor.

Alicia-Dorothy Mornington est maître de conférences à l'université Paris 1 Panthéon-Sorbonne. Elle est chercheure à l'Institut des Sciences Juridique et Philosophique de la Sorbonne, ainsi qu'au CEVIPOF à Sciences Po. Docteure en science politique et professeure agrégée d'anglais, sa recherche porte sur l'histoire des idées politiques du monde anglophone, en particulier sur le libéralisme et le libertarianisme. Elle a occupé plusieurs postes de recherche notamment à Oxford University (Nuffield college), à Columbia University, et à la London School of Economics.

\section{NOTES}

1. Toby Young, Cometh the Hour, Cometh the Man: A Profile of Boris Johnson, Quillette, Published on July 23, 2019, available at https://quillette.com/2019/07/23/cometh-the-hour-cometh-theman-a-profile-of-boris-johnson/

2. Election results 2019: Boris Johnson's victory speech in full, 13 December 2019, the BBC, available at https://www.bbc.com/news/election-2019-50777071

3. Conservative and Unionist Party manifesto, 2019, available at: https://assets-global.websitefiles.com/5da42e2cae7ebd3f8bde353c/ 5ddaa257967a3b50273283c4_Conservative\%202019\%20Costings.pdf

4. Norton, P., Aughey, A. (1981) Conservatives and Conservatism. London: Temple Smith, p 78.

5. Although as we shall see, it was appropriated by the Left as well, see notes 27 and 28.

6. Disraeli, Benjamin, Sybil, or the Two Nations, Wordsworth Collection, Wordsworth Classics, 1995, p 58.

7. Gladstone, William E., Speech, Liverpool, England, 28 June 1886 quoted in H. C. G. Matthew, Gladstone 1809-1898 (1997), Oxford, Oxford University Press, 2001, p. 349. See: Marshall, Catherine, Political Deference in a Democratic Age, Palgrave (forthcoming 2021).

8. Disraeli, Benjamin, Conservative and Liberal Principles: Speech at Crystal Palace, June 24, 1872. Adam Matthew Digital, 1882.

9. The conservatives passed the 1867 electoral reform, although it was in fact the brainchild of the Liberals. See Cowling, Maurice,1867 Disraeli, Gladstone and Revolution: The Passing of the Second Reform Bill. Cambridge University Press, 2005.

10. Lynch, Philip, The politics of nationhood: Sovereignty, Britishness and Conservative Politics. Springer, 1999, p 11. 
11. Dorey, Peter, British conservatism and trade unionism, 1945-1964, Ashgate Publishing, Ltd., 2009, p 170.

12. Marshall, Catherine, Political Deference in a Democratic Age, Palgrave (forthcoming 2021).

13. Briefing Paper, Number CBP 8749, 28 January 2020, General Election 2019: results and analysis, House of Commons Library, available at: https://commonslibrary.parliament.uk/ research-briefings/cbp-8749/

14. Party, Conservative. "Get Brexit Done: Unleash Britain's Potential”, Elections Manifesto (2019).

15. Election results 2019: Boris Johnson's victory speech in full, Speech given at the Queen Elizabeth II Centre, The BBC, 13 December 2019, available at : https://www.bbc.com/news/ election-2019-50777071

16. Johnson Boris, $13^{\text {th }}$ December 2019 speech in downing street, available at : https:// www.gov.uk/government/speeches/pm-statement-in-downing-street-13-december-2019

17. Savage, Michael, "Boris Johnson announces plans for spending spree in north", in The Guardian, 14 December 2019, available at: https://www.theguardian.com/politics/ 2019/dec/14/boris-johnson-plans-to-go-on-spending-spree-in-north

18. Stewart, Heather \& Halliday, Josh, "House of Lords may move out of London to 'reconnect' with public", in The Guardian, available at: https://www.theguardian.com/politics/2020/jan/19/ house-of-lords-may-move-out-of-london-to-reconnect-with-public

19. @BorisJohnson, 31 December 2019, Twitter, available at: https://twitter.com/i/status/ 1212141380425916416

20. Brogan, Benedict (29 April 2010), "My advice to David Cameron: I have made savings, so can you", The Telegraph, available at: https://www.telegraph.co.uk/news/election-2010/7653636/ Boris-Johnson-interview-My-advice-to-David-Cameron-Ive-made-savings-so-can-you.html

21. Robert Walsha "The One-nation Group and N Conservatism, 1950-2002", in Contemporary British History, 17:2, 2003, p 69.

22. Robert Walsha ibid, $\mathrm{p} 72$

23. Bochel, Hugh. "One Nation Conservatism and social policy, 1951-64", in Journal of Poverty and Social Justice 18, no. 2 (2010): pp. 123-134.

24. See Campbell, John, Edward Heath: a biography, Random House, 2013.

25. Dorey, Peter, \& Mark Garnett. “'The weaker-willed, the craven-hearted': the decline of One Nation Conservatism", in Global Discourse, 5, no. 1 (2015): pp. 69-91.

26. Walsha, Robert, ibid, p 18.

27. Walsha, Robert, ibid, p 72.

28. Or at least the interpretation of Hayek by Sir Keith Joseph and the Centre for Policy Studies. John Ranelagh famously reported that at a late 1970s meeting of the conservative party Margaret Thatcher allegedly banged a copy of Hayek's "The Constitution of Liberty" on the table and said, "this is what we believe in". See Ranelagh, John, Thatcher's People: An Insider's Account of the Politics, the Power, and the Personalities, London: Harper Collins, 1991.

29. Evans, Stephen, "The not so odd couple: Margaret Thatcher and one nation Conservatism", in Contemporary British History, vol 23, no. 1, 2009: pp. 101-121.

30. See Dorey, Peter, “The exhaustion of a tradition: The death of 'one nation' Toryism", in Contemporary Politics, 2, no. 4 (1996): pp. 47-65.

31. Walsha, Robert, ibid, p 73.

32. Hattersley, Roy \& Hickson, Kevin, The Socialist Way: Social Democracy in Contemporary Britain, I. B. Tauris, Jul 30, 2013, p 213. 
33. Alexandre-Collier, Agnès, Les habits neufs de David Cameron, Presses de Sciences Po, 2010, p 133. 34. Alexandre-Collier, Agnès, La démocratisation interne du Parti conservateur ou comment (re) devenir un "parti attrape-tout», in Observatoire de la Société Britannique, 2007, 4, pp. 35-47.

35. Dorey, Peter, "A new direction or another false dawn? David Cameron and the crisis of British conservatism”, British Politics, 2, no. 2 (2007): pp. 137-166.

36. Alexandre-Collier, Agnès «La démocratisation interne du Parti conservateur ou comment (re)devenir un " parti attrape-tout » », in Observatoire de la Société Britannique, 4, 2007, pp. 35-47, § 13.

37. PM and Chancellor announce 'one nation' plans to spread homeownership across the country, published 4 July 2015, from: HM Treasury, Prime Minister's Office, 10 Downing Street, Ministry of Housing, Communities \& Local Government, The Rt Hon David Cameron, and The Rt Hon George Osborne, Press release, available at: https://www.gov.uk/government/news/pmand-chancellor-announce-one-nation-plans-to-spread-homeownership-across-the-country

38. "My one nation government will close the gender pay gap", Press release, published 14 July 2015, from: Department for Business, Innovation \& Skills, Government Equalities Office, Prime Minister's Office, 10 Downing Street, and The Rt Hon David Cameron, available at: , https:// www.gov.uk/government/news/prime-minister-my-one-nation-government-will-close-thegender-pay-gap

39. "Prime Minister: One nation government backs British farmers", Press release, published 23 July 2015, from: Department for Environment, Food \& Rural Affairs, Prime Minister's Office, 10 Downing Street, Office of the Secretary of State for Wales, The Rt Hon David Cameron, The Rt Hon Stephen Crabb MP, and The Rt Hon Elizabeth Truss MP, available at https://www.gov.uk/ government/news/prime-minister-one-nation-government-backs-british-farmers

40. PM: New counter-extremism strategy is a clear signal of the choice we make today, Press release Published 19 October 2015, From: Home Office, Prime Minister's Office, 10 Downing Street, Disclosure and Barring Service, and The Rt Hon David Cameron, available at: https:// www.gov.uk/government/news/pm-new-counter-extremism-strategy-is-a-clear-signal-of-thechoice-we-make-today

41. "One Nation Science" Speech: Jo Johnson outlines the government's commitment to boost collaboration between business and universities and encourage diversity in STEM., Published 16 July 2015, From: Department for Business, Innovation \& Skills and The Rt Hon Jo Johnson, available online at: https://www.gov.uk/government/speeches/one-nation-science

42. Nicky Morgan: one nation education, Press Release, Published 3 November 2015 From: Department for Education and The Rt Hon Baroness Nicky Morgan, available online at: https:// www.gov.uk/government/speeches/nicky-morgan-one-nation-education

43. "Iain Duncan Smith: Wage rises show one nation government helping hardworking people", Press release, Published 12 August 2015, From: Department for Work and Pensions and The Rt Hon Iain Duncan Smith MP, available at: https://www.gov.uk/government/news/iain-duncansmith-wage-rises-show-one-nation-government-helping-hardworking-people

44. Seawright, David, The British Conservative Party and One Nation Politics, Bloomsbury Publishing USA, 2009, p 119.

45. On TINA, See Fisher, Mark. Capitalist Realism: Is There No Alternative, John Hunt Publishing, 2009, p 8.

46. Seawright, David, “One nation", In The Political Thought of the Conservative Party since 1945, London, Palgrave Macmillan, 2005, pp. 69-90.

47. According to the Trussell Trust, over a million 3-day emergency food supplies were handed out over 2016-17, out of which 400,000 claimants were children. See https:// www.trusselltrust.org/news-and-blog/latest-stats/end-year-stats/. Accessed 6 August 2018. 
48. Vail, Mark I., "Between One-Nation Toryism and Neoliberalism: The Dilemmas of British Conservatism and Britain's Evolving Place in Europe", in JCMS: Journal of Common Market Studies, 53, no. 1 (2015): pp. 106-122.

49. Fletcher, Martin, "The polite extremist: Jacob Rees-Mogg's seemingly unstoppable rise", in The New Statesman, 20 February 2018, https://www.newstatesman.com/politics/uk/2018/02/ polite-extremist-jacob-rees-mogg-s-seemingly-unstoppable-rise

50. Information relating to the European Research Group (ERG), I CAS-92438, Independent Parliamentary Standards Authority, 5 Oct 2017 https://www.theipsa.org.uk/publications/ freedom-of-information/2017-18/cas-92438/

51. Rees-Mogg, Jacob (6 August 2013). "Zero-hours contracts: why do Lefties always think they know best?", The Daily Telegraph, available at: https://www.telegraph.co.uk/news/politics/ 10225661/Zero-hours-contracts-why-do-Lefties-always-think-they-know-best.html

; George Parker, The Financial Times, September 29, 2017 "Cult Tory MP Jacob Rees-Mogg on Brexit and 'Moggmania"', available at: https://www.ft.com/content/05487a6ca371-11e7-9e4f-7f5e6a7c98a2

52. "Rees-Mogg: Food banks 'rather uplifting'". BBC News. 14 September 2017, available at: https://www.bbc.com/news/uk-politics-41264965

53. Kate Proctor, Rees-Mogg sorry for saying Grenfell victims lacked common sense, 5th November 2019, The Guardian, available at: https://www.theguardian.com/ politics/2019/nov/05/jacob-rees-mogg-claims-grenfell-victims-lacked-common-sense

54. Sir John Major accuses Dominic Cummings of 'poisoning' politics in thinly-veiled attack, The Independent, Friday 6 September 2019, available at: https://www.independent.co.uk/news/uk/ politics/john-major-dominic-cummings-cbi-speech-brexit-no-deal-conservatives-a9093906.html 55. Libertarianism is a theory with many branches, united by a strong distrust of the state, and a goal to repeal paternalism. The most famous and clearest advocate of this theory is Robert Nozick in his 1974 Anarchy State and Utopia. Libertarian nationalism could sound like a contradiction, and there are libertarians who argue against the existence of borders, (for example Kukathas), however, a majority of libertarians are comfortable with the idea of nation states, as long as they stick to Nozick's night-watchman theory of a minimal state and the principle of non-aggression. See: Nozick, Robert, Anarchy State and Utopia, Oxford, Blackwell, 1974; and Kukathas, Chandran, The Liberal Archipelago, A Theory of Diversity and Freedom, Oxford: Oxford University Press, 2003.

56. George Parker "Dominic Cummings has 'done' Brexit. Now he plans to reinvent politics", The Financial Times, January 16, 2020 https://www.ft.com/content/obf8a910-372e-11eaa6d3-9a26f8c3cba4

57. Dominic Cummings' Blog, “On the referendum \#21: Branching histories of the 2016 referendum and 'the frogs before the storm"', January 9, 2017, available at: https:// dominiccummings.com/tag/ukip/

58. Parker, George \& Bounds, Andy, “Brexit: will Boris Johnson reverse Thatcherism?", in The Financial Times, January 30, 2020, available at: https://www.ft.com/content/ 7ee8c8ec-41ba-11ea-a047-eae9bd51ceba

59. The Brexit Election, Part 1 (9pm-midnight), on Sky News, available at: https:// www.youtube.com/watch?v=ClsRXPwnnlk

60. Parker, George \& Bounds, ibid. 


\section{ABSTRACTS}

In the immediate aftermath of the 2019 general election, Boris Johnson repeatedly claimed he would form a "one-nation" conservative government. This article asks whether this pledge is to be taken at face value. To do so, this paper starts by explaining One-nation Conservatism, from its Disraelian roots to its use by the conservative party throughout the $20^{\text {th }}$ century. It then examines Johnson's self-branding as a One-nation conservative. It concludes by examining some of Johnson's decisions which shed some doubt on his one-nation commitment.

Le matin de l'élection de 2019, Boris Johnson a affirmé à plusieurs reprises qu'il formerait un gouvernement conservateur "One-nation " (de toute la nation). Quel sens donner à cette promesse ? Pour répondre à cette question, cet article commence par examiner le contenu théorique et le destin historique de ce type de conservatisme, de ses racines chez Disraeli à son utilisation par le parti conservateur tout au long du XXème siècle. Enfin, il examine le positionnement de Johnson et conclut que certaines de ses décisions jettent des doutes sur son positionnement « One-nation ».

INDEX

Keywords: 2019 general election, one-nation conservatism, Boris Johnson, Conservative Party Mots-clés: Élections britanniques de 2019, conservatisme one-nation, Boris Johnson, Parti conservateur 